\title{
Effects of Passivation on Synthesis, Structure and Composition of Mo- lybdenum Carbide Supported Platinum Water-Gas Shift Catalysts
}

\author{
Brian M. Wyvratt, Jason R. Gaudet, and Levi T. Thompson*
}

Department of Chemical Engineering, University of Michigan, Ann Arbor, MI, 48109

Hydrogen Energy Technology Laboratory, University of Michigan, Ann Arbor, MI 48109

*Corresponding Author: Levi T. Thompson, $\underline{\text { ltt@umich.edu }}$

\begin{abstract}
High surface area molybdenum carbides are attractive for use as catalysts and supports. Due to their pyrophoricity, carbides are typically passivated prior to use. Research described in this paper compared the synthesis, structural and compositional properties, and water gas shift activities of catalysts produced by depositing Pt onto unpassivated and passivated $\mathrm{Mo}_{2} \mathrm{C}$. Passivation had a profound effect on the character of interactions between the Pt precursor salt $\left(\mathrm{H}_{2} \mathrm{PtCl}_{6}\right)$ and $\mathrm{Mo}_{2} \mathrm{C}$. Nanoscale $\mathrm{Pt}$ metal particles were deposited onto the unpassivated $\mathrm{Mo}_{2} \mathrm{C}$ while very large Pt particles were deposited onto the passivated $\mathrm{Mo}_{2} \mathrm{C}\left(\mathrm{p}-\mathrm{Mo}_{2} \mathrm{C}\right)$. In situ X-ray absorption spectroscopy revealed reduction of $\mathrm{Pt}^{4+}$ on contact with the unpassivated $\mathrm{Mo}_{2} \mathrm{C}$ with commensurate oxidation of Mo. Water-gas shift activities were significantly higher for the $\mathrm{Pt} / \mathrm{Mo}_{2} \mathrm{C}$ compared to the $\mathrm{Pt} / \mathrm{p}-\mathrm{Mo}_{2} \mathrm{C}$ catalyst. Overall, the results indicate that the passivation of $\mathrm{Mo}_{2} \mathrm{C}$ prior to metal deposition had deleterious effects on the Pt loadings, structures, and activities.
\end{abstract}

Keywords: Platinum-Molybdenum carbide catalysts; water-gas shift; surface passivation; redox; in situ X-ray absorption spectroscopy 


\section{Introduction}

Supports play a critical role with regard to the performance of heterogeneous catalysts. The most important function of the support is typically to facilitate dispersion of the active phase although the support can also participate in the reaction $[1,2]$ and/or alter the electronic structure of the active phase $[3,4]$. A variety of supports have been investigated for catalytic applications (e.g., $\mathrm{Al}_{2} \mathrm{O}_{3}, \mathrm{SiO}_{2}, \mathrm{C}$ and zeolites) [5-8]. Early transition-metal carbides and nitrides offer unique properties as supports for both electrochemical [9] and chemical catalysts [10-12]. These materials can be synthesized with high surface areas $\left(>100 \mathrm{~m}^{2} / \mathrm{g}\right)[13]$ and can have catalytic properties that resemble to those of platinum group metals (e.g., Pd, Ru, Pt) [14]. Nitride- and carbide-supported metal catalysts have been reported to be active for chemical reactions including, but not limited to, hydrodenitrogenation and hydrodesulfurization [10,15], selective hydrogenations [12,16,17], Fischer-Tropsch Synthesis [18,19], methanol steam reforming [20,21], and water-gas shift [11,22], as well as electrochemical reactions such as the hydrogen evolution [9,23] and hydrogen oxidation reactions [24].

A practical challenge associated with the use of carbides and nitrides is their pyrophoricity; consequently prior to exposure to air, these materials are typically treated to form a passivation layer that prohibits bulk oxidation. As a result, most carbide- or nitride-supported metal catalysts reported in the literature were prepared by deposition or impregnation of the metal onto the passivated carbide or nitride surface $[12,15-19,23]$. Because the passivation layer is oxygen rich and metal at the surface of the carbide or nitride is oxidized [22], interactions between the passivated material and the deposited metal could be quite different from those for the native carbide or nitride. To date, there have been few reports of metal deposition onto unpassivated, native carbide or nitride supports $[11,20,25]$. These reports indicate that properties of the resulting materials can be somewhat unusual. Schweitzer et al. observed the formation of "raft-like" Pt particles on a $\mathrm{Mo}_{2} \mathrm{C}$ support with the resulting catalyst exhibiting water-gas shift activities that were superior to those for Pt supported on oxides, catalysts that are among the most active known [11]. Schaidle et al. investigated the deposition of a variety of late transition metals onto 
unpassivated $\mathrm{Mo}_{2} \mathrm{C}$ [25]. They reported that some metal precursors (e.g., $\mathrm{Pt}^{4+}, \mathrm{Pd}^{2+}, \mathrm{Cu}^{2+}$ ) were spontaneously reduced during deposition/interaction with the native $\mathrm{Mo}_{2} \mathrm{C}$ surface, suggesting the presence of surface redox chemistry (likely through oxidation of Mo). The possibility of redox chemistry is not surprising given that the carbides and nitrides are in a highly reduced state. The presence of a passivation layer should inhibit or prohibit this redox chemistry. Shou et al. reported effects of the passivation layer on $\mathrm{Rb}$-promoted $\mathrm{Mo}_{2} \mathrm{C}$-based $\mathrm{CO}$ hydrogenation catalysts [26]. The authors focused on defining effects of the presence of the passivation layer during reaction as opposed to during catalyst synthesis, noting that the "fresh" (unpassivated) $\mathrm{Rb} / \mathrm{Mo}_{2} \mathrm{C} / \mathrm{Al}_{2} \mathrm{O}_{3}$ performed similarly to its passivated counterpart. However, $\mathrm{Rb}^{+}$is very difficult to reduce $\left(\mathrm{E}^{\circ}=-2.93 \mathrm{~V}\right)$ and would likely not be spontaneously reduced upon interaction with $\mathrm{Mo}_{2} \mathrm{C}$ as observed with $\mathrm{Pt}^{4+}, \mathrm{Pd}^{2+}$, and $\mathrm{Cu}^{2+}\left(\mathrm{E}^{\circ}=0.74,1.13\right.$, and 0.34 , respectively) [27].

The aim of the research described in this paper was to systematically compare the compositional, structural and functional properties of unpassivated and passivated $\mathrm{Mo}_{2} \mathrm{C}$ supported $\mathrm{Pt}$ catalysts. In particular, we report similarities and differences in Pt deposition trends for these supports, results from characterization of the materials using techniques including in situ X-ray absorption spectroscopy (XAS), and their water gas shift activities. The water-gas shift reaction rates are compared to those for a commercial $\mathrm{Cu}-\mathrm{ZnO} / \mathrm{Al}_{2} \mathrm{O}_{3}$ catalyst, allowing a connection with the broader literature regarding water gas shift catalysis.

\section{Experimental Methods}

\section{Catalyst Synthesis}

Molybdenum carbide was synthesized via temperature-programmed reaction (TPR) as previously reported $[11,22,25]$. Approximately $1.3 \mathrm{~g}$ of ammonium paramolybdate $(125-250 \mu \mathrm{m})$ was loaded into a quartz flow-through reactor, supported by a bed of quartz wool, and secured in a vertical furnace. The precursor was heated from room temperature to $350^{\circ} \mathrm{C}$ under $\mathrm{H}_{2}$ flow $(400 \mathrm{~mL} / \mathrm{min})$ at a heating rate of 
$5^{\circ} \mathrm{C} / \mathrm{min}$ followed by a $12 \mathrm{hr}$ soak at this temperature. Following the soak step, $15 \% \mathrm{CH}_{4} / \mathrm{H}_{2}$ gas was introduced (400mL/ min) and the material was heated to $590{ }^{\circ} \mathrm{C}$ at $2.67{ }^{\circ} \mathrm{C} / \mathrm{min}$ followed by a $2 \mathrm{hr}$ soak. Upon completion of the reaction, the reactor was removed from the furnace and allowed to cool to room temperature.

When the reactor had cooled to below $30^{\circ} \mathrm{C}$, the material was treated in one of four ways: (1) transfer into an inert atmosphere glovebox without air exposure (referred to as $\mathrm{Mo}_{2} \mathrm{C}$ ), (2) surface passivation (material referred to as $\mathrm{p}-\mathrm{Mo}_{2} \mathrm{C}$ ), (3) Pt deposition onto $\mathrm{Mo}_{2} \mathrm{C}$ followed by reduction and passivation (to produce $\mathrm{Pt} / \mathrm{Mo}_{2} \mathrm{C}$ ), or (4) $\mathrm{Pt}$ deposition onto p- $\mathrm{Mo}_{2} \mathrm{C}$ followed by reduction and passivation (to produce $\mathrm{Pt} / \mathrm{p}-\mathrm{Mo}_{2} \mathrm{C}$ ). To passivate the surface, the material was exposed to $1 \% \mathrm{O}_{2} / \mathrm{He}$ flowing at $20 \mathrm{~mL} / \mathrm{min}$ for at least five hours. To obtain the unpassivated $\mathrm{Mo}_{2} \mathrm{C}$, the reactor was sealed and transferred into an inert atmosphere glove box without exposure to air. The third and fourth treatments involve the deposition of $\mathrm{Pt}$ onto the unpassivated or passivated $\mathrm{Mo}_{2} \mathrm{C}$ support via a wet impregnation method previously reported in detail for $\mathrm{Mo}_{2} \mathrm{C}$ [25]. In brief, the unpassivated or passivated $\mathrm{Mo}_{2} \mathrm{C}$ was transferred from the quartz reactor (without exposure to air) into a deaerated, aqueous solution of chloroplatinic acid $\left(\mathrm{H}_{2} \mathrm{PtCl}_{6} \bullet 6 \mathrm{H}_{2} \mathrm{O}\right)$, which was continuously sparged with Ar. The target Pt loading (approximately $4 \mathrm{wt} \%$ ) was selected to be consistent with previous work [11,21]. The Pt was allowed to deposit for up to $8 \mathrm{hrs}$. Following deposition, the catalyst was transferred back to the quartz reactor under argon blanket then reduced with $\mathrm{H}_{2}$ at $450^{\circ} \mathrm{C}$ for $4 \mathrm{hr}$. The material was then cooled and passivated as described above in order to inhibit bulk oxidation.

During the Pt deposition step, aliquots $(1.3 \mathrm{~mL})$ of the metal precursor solution were taken at discrete time intervals and filtered (Fisher, Sterile Nylon filters, $0.2 \mu \mathrm{m}$ pore size) prior to elemental analysis. A Varian 710-ES Inductively Coupled Plasma spectrometer was used to determine the concentration of Pt in solution and produce the deposition profiles.

To improve the surface-to-bulk ratio for Mo for the XAS experiments, $\mathrm{Al}_{2} \mathrm{O}_{3}$-supported $\mathrm{Mo}_{2} \mathrm{C}$ materials were synthesized by dry impregnation of $\gamma-\mathrm{Al}_{2} \mathrm{O}_{3}$ (Alfa Aesar, $78 \mathrm{~m}^{2} / \mathrm{g}$, pore volume of 0.40 
$\mathrm{cm}^{3} / \mathrm{g}$ ) with ammonium paramolybdate followed by carburization of the resulting material via temperature-programmed reaction using conditions described earlier. These materials were then transferred directly into an inert glove box and pelletized for use in the X-ray absorption experiments.

\section{Materials Characterization}

Surface areas and pore size distributions of the resulting catalysts were obtained using $\mathrm{N}_{2}$ physisorption (Micrometrics ASAP 2010). Surface areas were calculated using the Brunear-EmmettTeller method while micropore and mesopore size distributions were obtained by applying the HorváthKowazoe $(\mathrm{HK})$ and Barrett-Joyner-Halenda $(\mathrm{BJH})$ methods, respectively. X-ray diffraction analysis was performed using a Rigaku Miniflex XRD with $\mathrm{Cu} K \alpha$ radiation and a Ni filter $(\lambda=1.5418 \AA)$. An air-tight sample holder was used to obtain the diffraction pattern for unpassivated $\mathrm{Mo}_{2} \mathrm{C}$. The $2 \theta$ range $\left(10^{\circ}<2 \theta<90^{\circ}\right)$ was scanned at a rate of $5^{\circ} / \mathrm{min}$ with a $0.02^{\circ}$ step size. The final Pt loadings were determined by using a Varian 710-ES following digestion of $15 \mathrm{mg}$ of the catalyst in aqua regia (3:1 $\left.\mathrm{HCl}: \mathrm{HNO}_{3}\right)$.

Carbon monoxide chemisorption results were obtained using a Micromeritics Autochem 2910 instrument equipped with a thermal conductivity detector and a Pfeiffer Quadstar GSD 300 mass spectrometer. The catalysts $(\sim 100 \mathrm{mg})$ were pretreated in $15 \% \mathrm{CH}_{4} / \mathrm{H}_{2}(70 \mathrm{~mL} / \mathrm{min})$ at $590^{\circ} \mathrm{C}$ for $4 \mathrm{hr}$ followed by a $0.5 \mathrm{hr}$ purge step in $\mathrm{He}$ at $600^{\circ} \mathrm{C}$ to remove methane or hydrogen from the surface. The sample was then cooled to $35^{\circ} \mathrm{C}$. The catalyst was exposed to pulses of a mixture of $5 \% \mathrm{CO} / \mathrm{He}$ until surface saturation was observed. CO chemisorption capacities for these materials were calculated by comparing the area of the initial injection peaks to areas when the catalyst surface had been saturated.

Scanning electron micrographs of the catalysts were obtained using FEI Nova Nanolab Dualbeam (FIB/SEM). The materials were supported on sample holders using copper tape and were gold sputter coated to improve conductivity. Elemental analyses of specific micrographs were obtained using Energy Dispersive X-ray Spectroscopy (EDX). 
The point of zero charge ( $\mathrm{PZC}$, measured by $\mathrm{pH})$ measurements were carried out using procedures described in the literature $[25,28,29]$. The desired surface loading for PZC determination of $\mathrm{Mo}_{2} \mathrm{C}$ and $\mathrm{p}-\mathrm{Mo}_{2} \mathrm{C}$ was $500 \mathrm{~m}^{2} / \mathrm{L}$; the $\mathrm{Mo}_{2} \mathrm{C}$-based catalyst weight was maintained at approximately $40 \mathrm{mg}$ per solution. The $\mathrm{pH}$ of the starting solution (deionized water purged with Ar) was adjusted using concentrated hydrochloric acid or ammonium hydroxide to meet a target starting $\mathrm{pH}$ value. The catalyst sample was added to the solution, and the $\mathrm{pH}$ was recorded as a function of time until it stabilized at a final $\mathrm{pH}$ value. Due to the low surface area of $\mathrm{MoO}_{2}\left(\sim 4 \mathrm{~m}^{2} / \mathrm{g}\right), 500 \mathrm{mg}$ of material was used in order to maintain the desired surface loading.

To analyze the dynamic deposition and spontaneous reduction (previously reported by Schaidle et al. [25]) of Pt, in situ X-ray absorption experiments were conducted at the Advanced Photon Source at Argonne National Laboratory. A custom cell (see Supporting Information) was designed to allow for the in situ analysis; both the Mo K $(20,000 \mathrm{eV})$ and Pt L3 $(11,653 \mathrm{eV})$ edges were analyzed during separate deposition studies.

To conduct the in situ experiments, pellets of the unpassivated $\mathrm{Mo}_{2} \mathrm{C}$ and $\mathrm{Mo}_{2} \mathrm{C} / \mathrm{Al}_{2} \mathrm{O}_{3}$ were prepared and secured in the XAS cell, which was subsequently purged with $\mathrm{N}_{2}$ flow. A spectrum of the Mo $\mathrm{K}$ or Pt L3 edge was obtained prior to introduction of the $\mathrm{H}_{2} \mathrm{PtCl}_{6} \bullet 6 \mathrm{H}_{2} \mathrm{O}$ solution. The deaerated solution was then introduced through a septum and XANES spectra were continuously collected over five hours. The $\mathrm{Mo}_{2} \mathrm{C}$ pellet and the final precursor solution were retained for subsequent elemental analysis. A more detailed description of the custom cell and in situ experiments can be found in the SI. Spectra were analyzed using the Demter software package [30]. The Pt and Mo oxidation states were determined based on spectra obtained for metal standards $\left(\mathrm{Pt}: \mathrm{H}_{2} \mathrm{PtCl}_{6}, \mathrm{Pt}^{0} ; \mathrm{Mo}: \mathrm{MoO}_{3}, \mathrm{MoO}_{2}, \mathrm{Mo}^{0}\right)$ using linear combination fitting.

\section{Water-Gas Shift Activity Measurements}

The water-gas shift activities were determined using a flow reactor equipped with a GC-TCD (SRI 8610, Carboxen 1000). Prior to obtaining the activity data, all of the $\mathrm{Mo}_{2} \mathrm{C}$-based catalysts were 
pretreated in $15 \% \mathrm{CH}_{4} / \mathrm{H}_{2}$ at $590^{\circ} \mathrm{C}$ for $4 \mathrm{hr}\left(10^{\circ} \mathrm{C} / \mathrm{min}\right.$ heat rate $)$ to remove the passivation layer. The commercial $\mathrm{Cu}-\mathrm{ZnO} / \mathrm{Al}_{2} \mathrm{O}_{3}$ was pretreated in $4 \% \mathrm{H}_{2} / \mathrm{N}_{2}$ at $200^{\circ} \mathrm{C}$ for $4 \mathrm{hr}\left(3^{\circ} \mathrm{C} / \mathrm{min}\right.$ heat rate $)$ per vendor specifications. The reactant feed consisted of $11 \% \mathrm{CO}, 21 \% \mathrm{H}_{2} \mathrm{O}, 6 \% \mathrm{CO}_{2}, 43 \% \mathrm{H}_{2}$, and $19 \% \mathrm{~N}_{2}(262$ $\mathrm{mL} / \mathrm{min}, 125,000 \mathrm{hr}^{-1}$ ) to simulate commercial reformate streams and the temperature was varied between 200 and $240^{\circ} \mathrm{C}$. Prior to injection into the GC, the effluent stream flowed through a condenser, held at $0^{\circ} \mathrm{C}$ to remove water from the stream.

Differential conditions were maintained by limiting the conversions to $10 \%$; this was accomplished by adjusting the catalyst weight. The catalyst was diluted with low surface area $\mathrm{SiO}_{2}(\mathrm{Alfa}$ Aesar, $99.995 \%$ metals basis) in order to maintain a constant bed height and volume. Hydrogen production rates were determined by monitoring the consumption of $\mathrm{CO}$; mass balance closure was confirmed by quantifying the formation of $\mathrm{CO}_{2}$. Direct measurement of $\mathrm{H}_{2}$ was not possible because we used He as the carrier gas. Arrhenius plots for the turnover frequencies (TOF, $\mathrm{s}^{-1}$ ), CO consumption rates normalized by $\mathrm{CO}$ uptakes, are reported for each of the catalysts.

\section{Results}

Material Characterization 
X-ray diffraction patterns for the $\mathrm{Mo}_{2} \mathrm{C}$ and $\mathrm{p}-\mathrm{Mo}_{2} \mathrm{C}$ materials contained peaks characteristic for

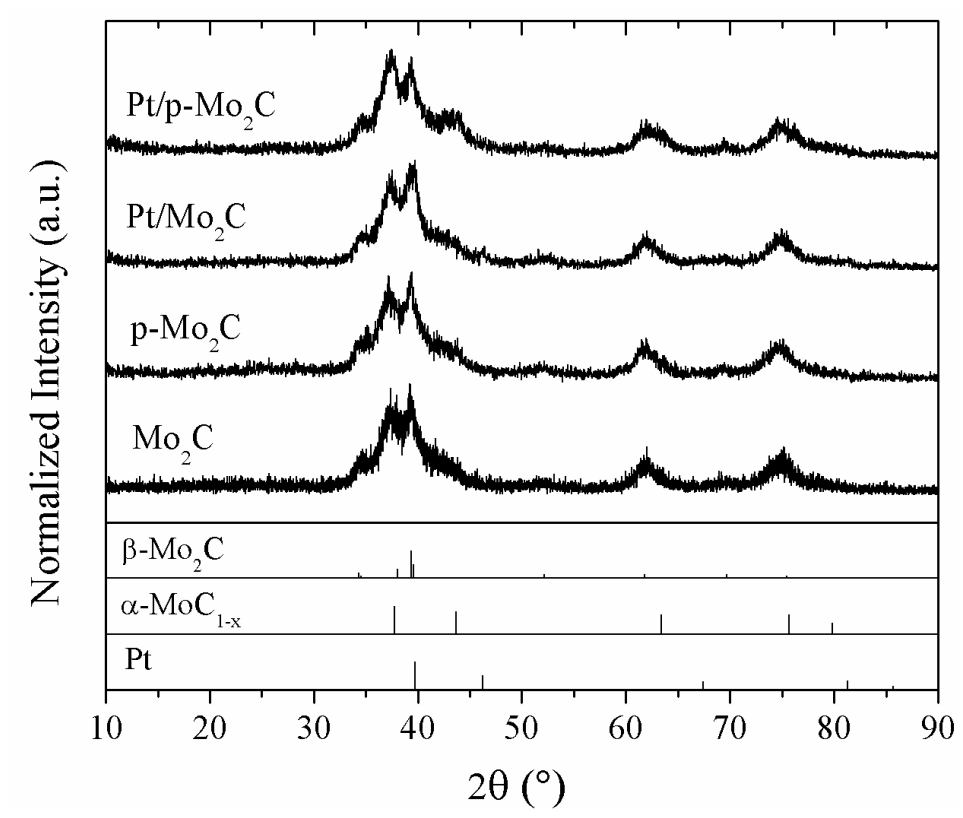

Figure 1. X-ray diffraction patterns for the studied catalysts, including standards from ICDD $\left(\beta-\mathrm{Mo}_{2} \mathrm{C}[\mathrm{PDF}\right.$ \#04-001-2151], $\alpha-\mathrm{MoC}_{1-\mathrm{x}}$ [PDF \#04-001-2968], Pt [PDF \#98-001-3679].

$\alpha-\mathrm{MoC}_{1-\mathrm{x}}$ and $\beta-\mathrm{Mo}_{2} \mathrm{C}$ (Figure 1). For these catalysts, there was no evidence of oxide phases indicating that carburization was complete and that formation of the passivation layer was restricted to the surface, or that any other species were amorphous or below the detection limits for the diffractometer $(\sim 5 \mathrm{~nm})$. The surface area decreased significantly from 162 to $103 \mathrm{~m}^{2} / \mathrm{g}$ upon passivating the $\mathrm{Mo}_{2} \mathrm{C}$ materials. This loss of surface area corresponds to the loss of micropores during passivation as observed in the pore size distributions (Figure 2); the mesopore densities are very similar. 

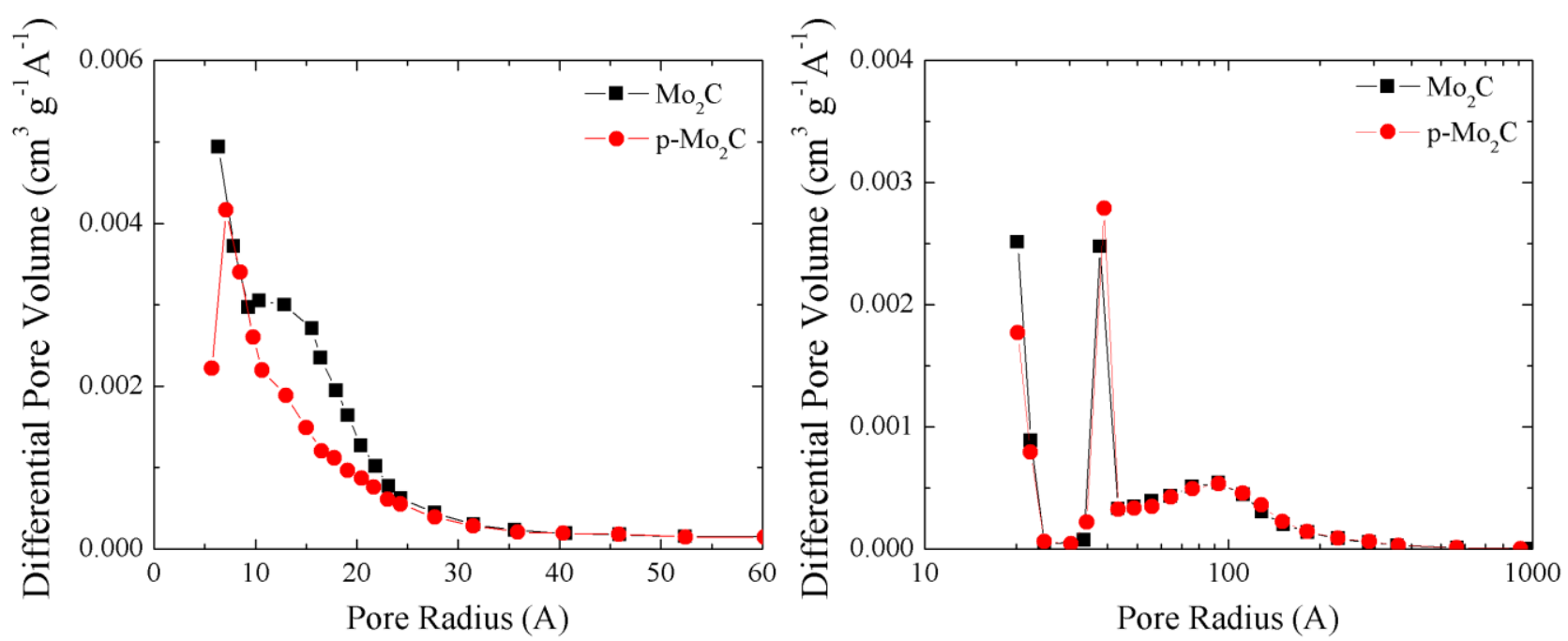

Figure 2. Pore size distributions in unpassivated and passivated $\mathrm{Mo}_{2} \mathrm{C}$ for (a) micropores determined using the Horváth-Kowazoe (HK) method and (b) mesopores determined using the Barrett-JoynerHalenda (BJH) method.

\section{Platinum Deposition}

The deposition of Pt onto the $\mathrm{Mo}_{2} \mathrm{C}$ and $\mathrm{p}-\mathrm{Mo}_{2} \mathrm{C}$ supports was quantified by monitoring the concentration of Pt in the supernatant solution as a function of deposition time. Figure 3 indicates very rapid deposition of Pt onto the $\mathrm{Mo}_{2} \mathrm{C}$ surface. Conversely, Pt deposition onto the $\mathrm{p}-\mathrm{Mo}_{2} \mathrm{C}$ surface occurred in two stages. During the initial stage, the deposition of Pt approached an asymptote corresponding to $\sim 25 \%$ of the Pt in the original solution. After approximately 150 min, additional Pt deposition occurred at a slower rate until essentially all of the Pt was removed from the solution. This deposition trend was reproducible for separate experiments with the discontinuity in the adsorption curve occurring at times between 120 and 180 minutes. 
Coincident with changes in the Pt concentrations, there were distinct color changes for the aqueous solutions (see Supporting Information). During deposition of Pt onto $\mathrm{Mo}_{2} \mathrm{C}$, the metal precursor solution changed from yellow to clear. During deposition of $\mathrm{Pt}$ onto $\mathrm{p}-\mathrm{Mo}_{2} \mathrm{C}$, the solution remained yellow for the first 120-180 min. Subsequently, the aqueous solution began to turn blue. Following deposition of Pt onto $\mathrm{p}-\mathrm{Mo}_{2} \mathrm{C}$, the aqueous solution was dark blue. We believe the coloration was due to dissolution of some or all of the passivation layer, likely a molybdenum oxycarbide. Placing $\mathrm{p}-\mathrm{Mo}_{2} \mathrm{C}$ into deionized water (without $\mathrm{H}_{2} \mathrm{PtCl}_{6}$ ) also resulted in the formation of this blue color. The material that gave rise to the blue color was filtered out of the solution prior to elemental analysis to avoid introduction of any particulates into the ICP. Water was evaporated from this blue solution and the resulting solid was characterized. The material was $\mathrm{x}$-ray amorphous and contained $62 \pm 7 \mathrm{wt} \% \mathrm{Mo}$; for comparison, $\mathrm{MoO}_{3}$ contains $67 \mathrm{wt} \%$ Mo and $\mathrm{MoO}_{2}$ contains $75 \mathrm{wt} \%$ Mo. The results are not inconsistent with the blue material being an oxycarbide.

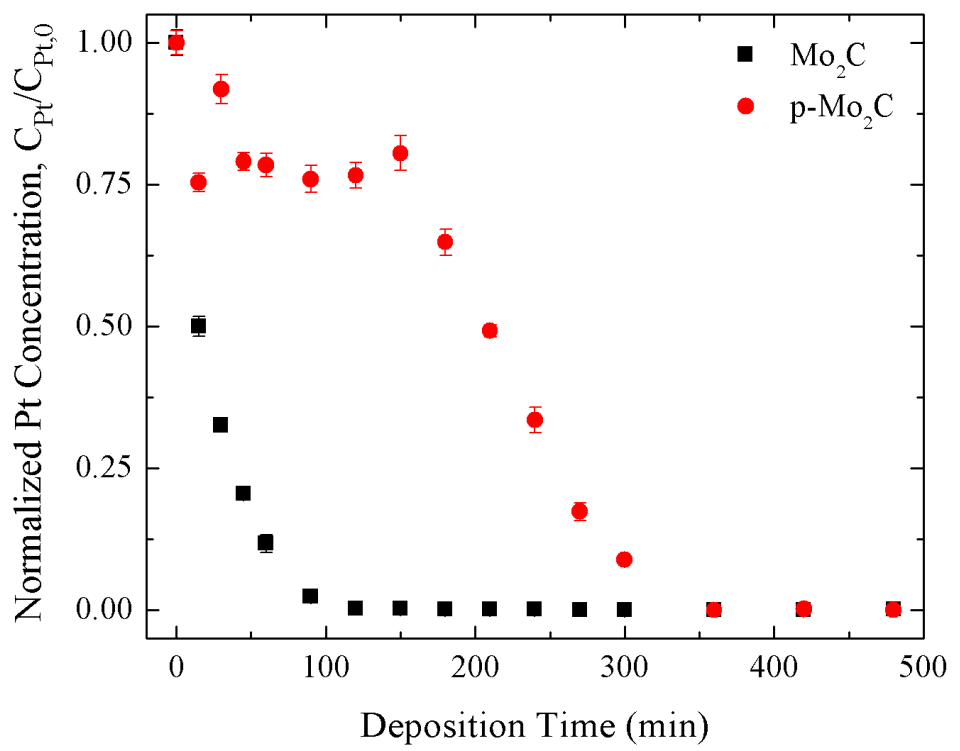

Figure 3. Profiles for $\mathrm{Pt}$ deposition $\left(\mathrm{H}_{2} \mathrm{PtCl}_{6}\right.$ precursor $)$ onto $\mathrm{Mo}_{2} \mathrm{C}(\boldsymbol{\bullet})$ and $\mathrm{p}-\mathrm{Mo}_{2} \mathrm{C}(\bullet)$.

Analysis of the resulting catalysts indicated that the $\mathrm{Pt} / \mathrm{Mo}_{2} \mathrm{C}$ catalyst contained $3.7 \mathrm{wt} \% \mathrm{Pt}$ and the Pt/p- $\mathrm{Mo}_{2} \mathrm{C}$ catalyst contained $1.1 \mathrm{wt} \% \mathrm{Pt}$. The actual $\mathrm{Pt}$ loading for the $\mathrm{Pt} / \mathrm{Mo}_{2} \mathrm{C}$ catalyst was within experimental error of the amount of Pt removed from the deposition solution (equivalent to 3.9wt\% Pt). The Pt loading for the $\mathrm{Pt} / \mathrm{p}-\mathrm{Mo}_{2} \mathrm{C}$ catalyst was significantly less than the amount of Pt removed from the 
solution (equivalent to $3.8 \mathrm{wt} \%$ ). The basis for this observation will be considered in the Discussion section.

Differences between $\mathrm{Pt}$ deposition profiles and compositions for the $\mathrm{Mo}_{2} \mathrm{C}$ and $\mathrm{p}-\mathrm{Mo}_{2} \mathrm{C}$ supports suggest different deposition mechanisms. The deposition of Pt onto Mo carbides has been reported to proceed via electrostatic adsorption of the $\mathrm{Pt}$ ions followed by reduction on the $\mathrm{Mo}_{2} \mathrm{C}$ [25]. The point of zero charge (PZC) is a useful metric with regard to the surface chemistry of materials in solution [28,29]. The PZC of a material characterizes the point at which surface functional groups (e.g. hydroxyl) equilibrate with the solution such that no net protonation or deprotonation of surface $-\mathrm{OH}$ groups occurs. Solutions of initial $\mathrm{pH}$ above or below the PZC will deprotonate and protonate surface hydroxyls, respectively, in an attempt to equilibrate the material-solution system. If the $\mathrm{PZC}$ of $\mathrm{Mo}_{2} \mathrm{C}$ or $\mathrm{p}$ $\mathrm{Mo}_{2} \mathrm{C}$ lies sufficiently far above the $\mathrm{pH}$ of the metal precursor solution, the material surface will generate a positive surface charge; the $\left[\mathrm{PtCl}_{6}\right]^{2-}$ anion will then be attracted to the surface and adsorb electrostatically.

Results from the PZC experiments for the $\mathrm{Mo}_{2} \mathrm{C}$, p- $\mathrm{Mo}_{2} \mathrm{C}$, and $\mathrm{MoO}_{2}$ materials are shown in Figure 4. The flat portion of each curve represents the point of zero charge. The $\mathrm{PZC}$ for $\mathrm{Mo}_{2} \mathrm{C}$ is ap-

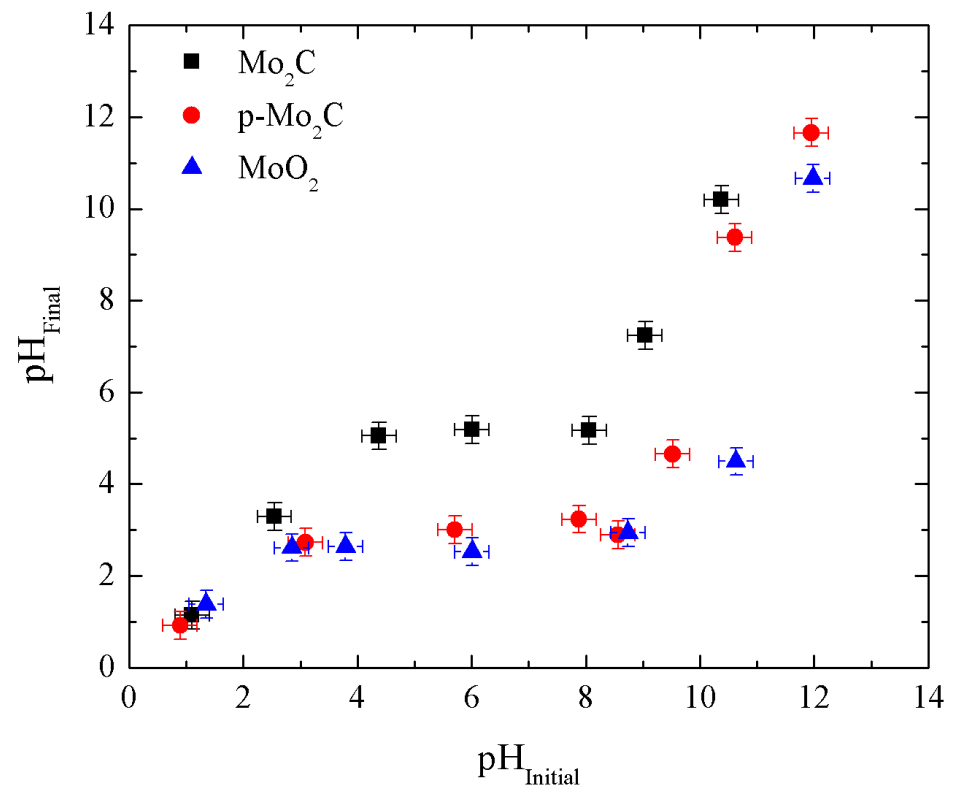

Figure 4. Point of zero charge determination for the $\mathrm{Mo}_{2} \mathrm{C}, \mathrm{p}-\mathrm{Mo}_{2} \mathrm{C}$ and $\mathrm{MoO}_{2}$ materials. 
proximately $\mathrm{pH} 5$, while $\mathrm{PZCs}$ for the $\mathrm{p}-\mathrm{Mo}_{2} \mathrm{C}$ and $\mathrm{MoO}_{2}$ materials are very similar and approximately $\mathrm{pH}$ 3. These results not only indicate that surface chemistries of the unpassivated and passivated $\mathrm{Mo}_{2} \mathrm{C}$ surfaces are different, but that the charge of the $\mathrm{p}-\mathrm{Mo}_{2} \mathrm{C}$ surface in solution at a given $\mathrm{pH}$ resembles that of $\mathrm{MoO}_{2}$. For completeness the $\mathrm{PZC}$ for $\mathrm{MoO}_{3}$ was estimated and found to be approximately $\mathrm{pH} 3$ in acidic solutions, but this result is not reported since $\mathrm{MoO}_{3}$ dissolves in basic solutions.

\section{In situ X-ray Absorption Spectroscopy}

Schaidle et al. reported that during the preparation of $\mathrm{Mo}_{2} \mathrm{C}$ supported metal catalysts, select metal ions (e.g., $\left[\mathrm{PtCl}_{6}\right]^{2-},\left[\mathrm{Pd}\left(\mathrm{NH}_{3}\right)_{4}\right]^{2+}, \mathrm{Cu}^{2+}$ ) were reduced on interaction with $\mathrm{Mo}_{2} \mathrm{C}$ while others (e.g., $\mathrm{Ni}^{2+}, \mathrm{Fe}^{2+}$ ) were not [25]. They proposed that redox reactions occurred between the $\mathrm{Mo}_{2} \mathrm{C}$ surface and metal precursor such that metal reduction was accompanied by Mo oxidation. To probe for evidence of redox reactions, the $\mathrm{Pt}$ ( $\mathrm{Pt} \mathrm{L} 3$ edge) and Mo (Mo K edge) chemical states were monitored by X-ray absorption spectroscopy during the interaction of aqueous solutions of $\mathrm{H}_{2} \mathrm{PtCl}_{6}$ with $\mathrm{Mo}_{2} \mathrm{C}$ (see Figure 5). A small degree of Mo oxidation was observed during Pt deposition (13wt\%, 25\% surface coverage assuming $10^{19}$ sites $/ \mathrm{m}^{2}$ ) onto bulk, unpassivated $\mathrm{Mo}_{2} \mathrm{C}$ as indicated by the edge shift from 20008 to
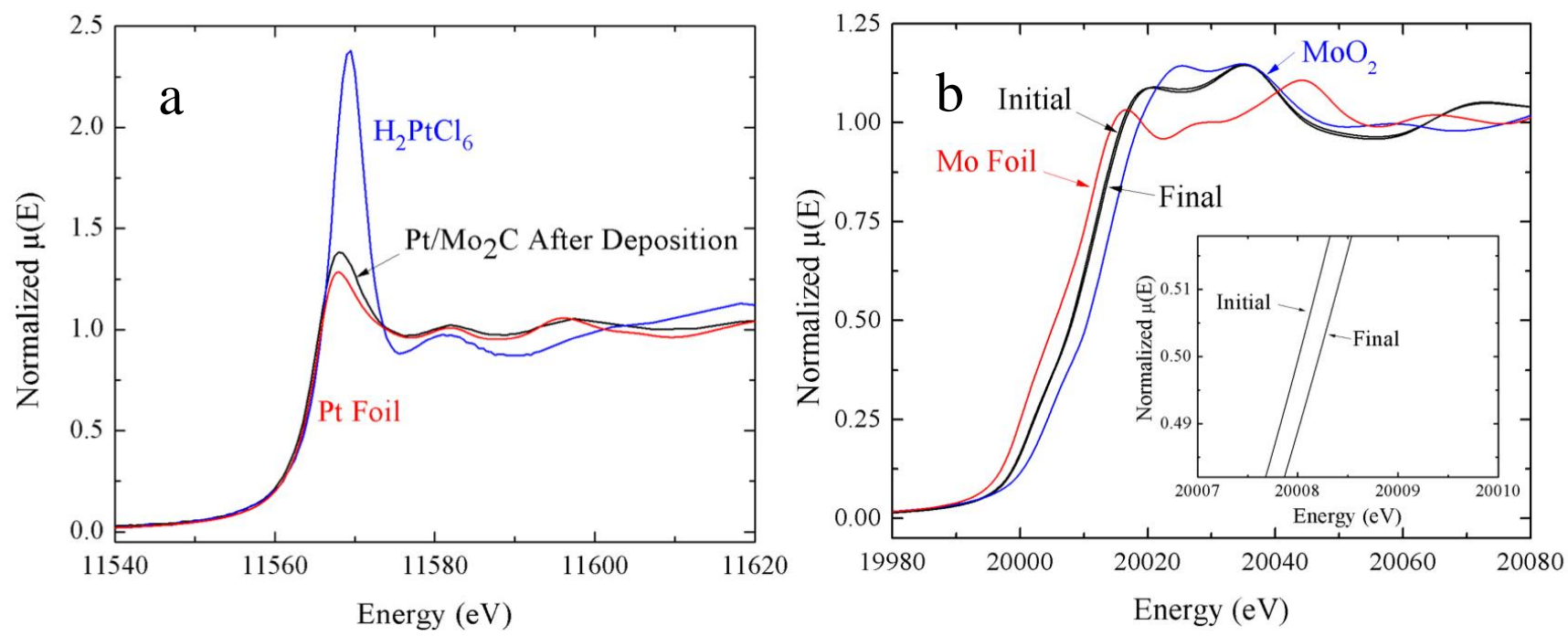

Figure 5. (a) Pt L3 edge spectra for $14.3 \mathrm{wt} \% \mathrm{Pt} / \mathrm{Mo}_{2} \mathrm{C}$ following metal deposition as well as spectra for $\mathrm{H}_{2} \mathrm{PtCl}_{6}$ (blue line) and $\mathrm{Pt}^{(0)}$ (red line) standards. (b) Initial and final Mo K edge spectra for $14.3 \%$ $\mathrm{Pt} / \mathrm{Mo}_{2} \mathrm{C}$ following $\mathrm{Pt}$ deposition onto bulk $\mathrm{Mo}_{2} \mathrm{C}$ as well as spectra for Mo metal (red line) and $\mathrm{MoO}_{2}$ standards (blue line). 
$\sim 20008.2 \mathrm{eV}$ at a normalized $\mu(\mathrm{E})$ value of 0.5 , while the $\mathrm{Pt}$ was reduced from $\mathrm{Pt}^{4+}$ (the formal oxidation state for $\mathrm{Pt}$ in $\mathrm{H}_{2} \mathrm{PtCl}_{6}$ ) to approximately $\mathrm{Pt}^{0.4+}$ as evidenced by the loss of the strong white line signal present in oxidized $\mathrm{Pt}$ and an edge shift to lower energy. The average oxidation states of Mo and $\mathrm{Pt}$ were determined using linear combination fitting to known standards. By quantifying the electrons required to reduce the deposited $\mathrm{Pt}$ from $\mathrm{Pt}^{4+}$ to $\mathrm{Pt}^{(0)}$ as measured by elemental analysis of the solution before and after deposition, the expected change in oxidation state of Mo was +0.20 . The measured change in oxidation state derived from linear combination fitting was +0.18 , in close agreement with the expected change. However, this change in oxidation state is relatively small. To enhance the signal to noise ratio, the experiment was repeated with $\mathrm{Mo}_{2} \mathrm{C}$ dispersed onto $\gamma-\mathrm{Al}_{2} \mathrm{O}_{3}$. The use of $\mathrm{Mo}_{2} \mathrm{C} / \mathrm{Al}_{2} \mathrm{O}_{3}$ improves the surface to bulk ratio allowing for easier quantification of Mo oxidation. The chemistry of $\mathrm{Mo}_{2} \mathrm{C} / \mathrm{Al}_{2} \mathrm{O}_{3}$ has been reported to be comparable to those for bulk $\mathrm{Mo}_{2} \mathrm{C}$ [31]. Platinum (6 wt\% equivalent, based on the work by Wang et al. [31]) was deposited onto $20 \mathrm{wt} \% \mathrm{Mo}_{2} \mathrm{C} / \mathrm{Al}_{2} \mathrm{O}_{3}$ while recording spectra. The results of these experiments are shown in Figures 6 and 7. The Pt L3 edge XANES spectra (shown in Figure 6a) changed dramatically during Pt deposition. The results are consistent with the reduction of $\mathrm{Pt}^{4+}$ in $\mathrm{H}_{2} \mathrm{PtCl}_{6}$ to metallic Pt. Observing isosbestic points at 11.573 and $11.602 \mathrm{keV}$, it is evident that the spectra can be deconvoluted as a linear combination of at least two known standards $(\mathrm{Pt}$ metal and $\mathrm{H}_{2} \mathrm{PtCl}_{6}$ in this case). This deconvolution was used to estimate the average oxidation states as shown in Figure 7a. The Pt oxidation state decreased rapidly from $+4\left(\mathrm{H}_{2} \mathrm{PtCl}_{6}\right)$ to +0.5 after 4 hours of interaction with $\mathrm{Mo}_{2} \mathrm{C}$. Similar to results observed for the bulk $\mathrm{Mo}_{2} \mathrm{C}$ support, the oxidation state did not reach zero, likely due to the presence of oxidized Pt remaining in solution (approximately $9 \%$ of the initial concentration as determined by elemental analysis of the final solution). 

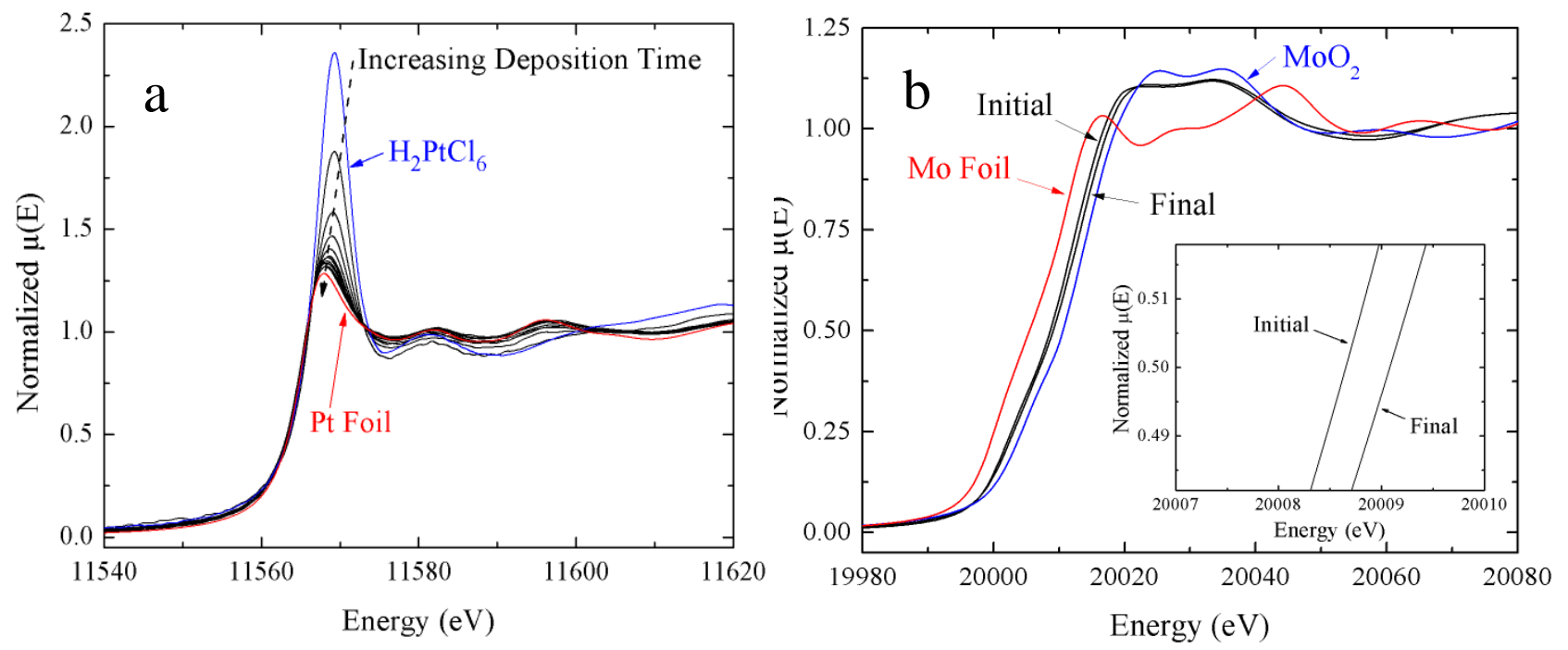

Figure 6. (a) Pt L3 edge XANES spectra during Pt (6wt\%) deposition onto $\mathrm{Mo}_{2} \mathrm{C} / \mathrm{Al}_{2} \mathrm{O}_{3}$. The spectrum for $\mathrm{H}_{2} \mathrm{PtCl}_{6}$ (blue) is at the top. The reference spectrum for metallic $\mathrm{Pt}$ is shown at the bottom (red). (b) Mo K edge XANES spectra of $\mathrm{Mo}_{2} \mathrm{C} / \mathrm{Al}_{2} \mathrm{O}_{3}$ before and after Pt deposition. The inset represents a closer view of the edge shift. Metallic Mo (red line) and Mo (IV) oxide (blue line) are shown for reference.

Figure $6 \mathrm{~b}$ illustrates the Mo $\mathrm{K}$ edge spectra before and after deposition. The change in Mo $\mathrm{K}$ edge was more subtle than that for Pt given the lack of a strong white line for Mo as is present for Pt. Nevertheless, an edge shift to higher energy was again observed indicative of oxidation. By

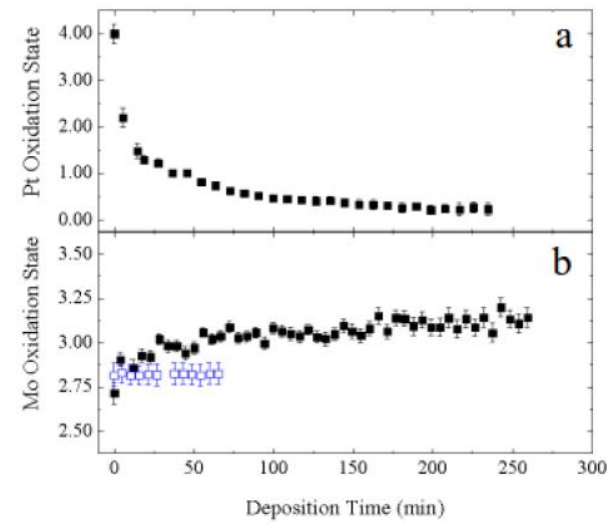

Figure 7. Average oxidation state of (a) Pt and (b) Mo in $\mathrm{Mo}_{2} \mathrm{C} / \mathrm{Al}_{2} \mathrm{O}_{3}$ catalyst as a function of $\mathrm{Pt}$ deposition time. Open blue points in (B) represent the blank experiment (only dearated water, no $\mathrm{H}_{2} \mathrm{PtCl}_{6}$ ). 
$\mathrm{Pt}$ had little effect on the surface area. The $\mathrm{CO}$ chemisorption capacities for the $\mathrm{p}-\mathrm{Mo}_{2} \mathrm{C}$ and $\mathrm{Pt} / \mathrm{p}-\mathrm{Mo}_{2} \mathrm{C}$ catalysts, following recarburization, were comparable, while the chemisorption capacity was lower for the $\mathrm{Pt} / \mathrm{Mo}_{2} \mathrm{C}$ catalyst relative to $\mathrm{Mo}_{2} \mathrm{C}$. This decrease is likely a consequence of differences in the adsorption capacities of $\mathrm{Pt}$ and $\mathrm{Mo}_{2} \mathrm{C}$. Based on the surface areas, $\mathrm{Pt}$ surface coverages for the $\mathrm{Pt} / \mathrm{Mo}_{2} \mathrm{C}$ and $\mathrm{Pt} / \mathrm{p}-\mathrm{Mo}_{2} \mathrm{C}$ were equivalent to 9.9 and $3.1 \%$ of a monolayer based on $10^{19}$ atoms $/ \mathrm{m}^{2}$, respectively. Differences between $\mathrm{CO}$ uptakes for the $\mathrm{Pt} / \mathrm{Mo}_{2} \mathrm{C}$ and $\mathrm{Pt} / \mathrm{p}-\mathrm{Mo}_{2} \mathrm{C}$ catalysts could also be due to differences in the character or dispersion of Pt. This decrease following the addition of Pt has been observed previously [22].

Scanning electron micrographs and EDX mapping indicated very different morphologies for Pt on the $\mathrm{Pt} / \mathrm{Mo}_{2} \mathrm{C}$ and $\mathrm{Pt} / \mathrm{p}-\mathrm{Mo}_{2} \mathrm{C}$ catalysts (Figure 8). Small particles of $\mathrm{Pt}$ were uniformly dispersed on the $\mathrm{Mo}_{2} \mathrm{C}$ surface for the $\mathrm{Pt} / \mathrm{Mo}_{2} \mathrm{C}$ catalyst. Conversely, the $\mathrm{Pt} / \mathrm{p}-\mathrm{Mo}_{2} \mathrm{C}$ catalyst contained very large agglomerates of $\mathrm{Pt}(19 \pm 6 \mu \mathrm{m}$, when averaged over 10 particles observed) randomly dispersed on the $\mathrm{Mo}_{2} \mathrm{C}$ surface. EDX mapping confirmed that these agglomerates were Pt particles. The observation of large Pt particles on the Pt/p- $\mathrm{Mo}_{2} \mathrm{C}$ catalyst is inconsistent with the XRD results. This discrepancy could

a)

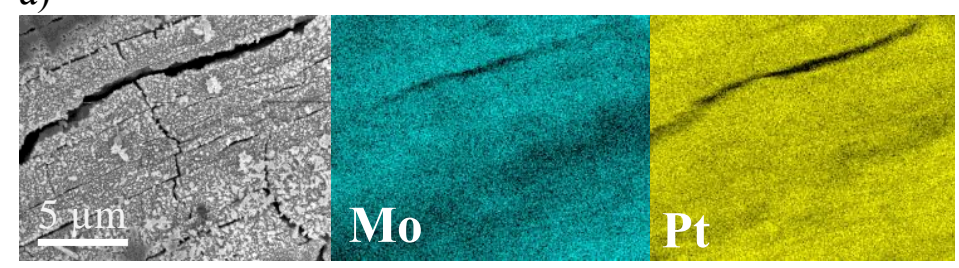

b)

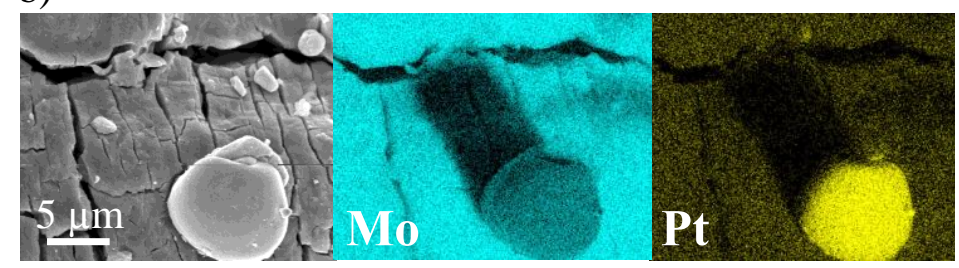

Figure 8. Scanning electron micrographs and corresponding EDX spectra for the a) $\mathrm{Pt} / \mathrm{Mo}_{2} \mathrm{C}$ and b) $\mathrm{Pt} / \mathrm{p}$ $\mathrm{Mo}_{2} \mathrm{C}$ catalysts.

be a consequence of the low loading for this catalyst. We also note that, the most intense peak for Pt $\left(39.8^{\circ}\right.$, corresponding to $(111)$ plane) is very close to that for $\beta-\mathrm{Mo}_{2} \mathrm{C}\left(39.4^{\circ}\right.$, corresponding to (121) 
plane); this could lead to interference for the $\mathrm{Pt} / \mathrm{p}-\mathrm{Mo}_{2} \mathrm{C}$ and $\mathrm{Pt} / \mathrm{Mo}_{2} \mathrm{C}$ catalysts. Nevertheless Pt morphologies for these catalysts were very different. The implications will be considered later.

\section{Catalytic Activity}

Water-gas shift (WGS) turnover frequencies, based on $\mathrm{CO}$ uptakes, for the $\mathrm{Mo}_{2} \mathrm{C}$-based and commercial $\mathrm{Cu}-\mathrm{ZnO} / \mathrm{Al}_{2} \mathrm{O}_{3}$ catalysts are shown in Figure 9. Turnover frequencies for the $\mathrm{Pt} / \mathrm{Mo}_{2} \mathrm{C}$ was significantly higher than those for the other materials including the $\mathrm{Cu}-\mathrm{ZnO} / \mathrm{Al}_{2} \mathrm{O}_{3}$ catalyst while the activation energy was lower than that for the $\mathrm{Pt} / \mathrm{p}-\mathrm{Mo}_{2} \mathrm{C}$ and $\mathrm{p}-\mathrm{Mo}_{2} \mathrm{C}$ catalysts but comparable to that for the $\mathrm{Cu}-\mathrm{ZnO} / \mathrm{Al}_{2} \mathrm{O}_{3}$ catalyst (Table 1). The activation energies for the $\mathrm{p}-\mathrm{Mo}_{2} \mathrm{C}$ and $\mathrm{Pt} / \mathrm{p}-\mathrm{Mo}_{2} \mathrm{C}$ catalysts were similar. Furthermore, activation energies for the p- $\mathrm{Mo}_{2} \mathrm{C}, \mathrm{Pt} / \mathrm{Mo}_{2} \mathrm{C}$, and $\mathrm{Cu}-\mathrm{ZnO} / \mathrm{Al}_{2} \mathrm{O}_{3}$ catalysts are in agreement with those reported previously [11,22,32]. Interestingly, when normalized by the Pt content, activities for the $\mathrm{Pt} / \mathrm{p}-\mathrm{Mo}_{2} \mathrm{C}\left(1.4 \mathrm{~mol}_{\mathrm{CO}} \mathrm{mol}_{\mathrm{Pt}}{ }^{-1} \mathrm{~s}^{-1}\right)$ and $\mathrm{Pt} / \mathrm{Mo}_{2} \mathrm{C}\left(1.3 \mathrm{~mol}_{\mathrm{CO}} \mathrm{mol}_{\mathrm{Pt}}{ }^{-1} \mathrm{~s}^{-1}\right) \mathrm{cata}^{-}$ lysts were similar. This similarity will be considered in the Discussion section. The Pt normalized rate for the $\mathrm{Pt} / \mathrm{Mo}_{2} \mathrm{C}$ catalysts matches closely with those reported by Schweitzer et al. $\left(\sim 1.4 \mathrm{~mol}_{\mathrm{CO}} \mathrm{mol}_{\mathrm{Pt}}{ }^{-1} \mathrm{~s}^{-}\right.$ 1) [11].

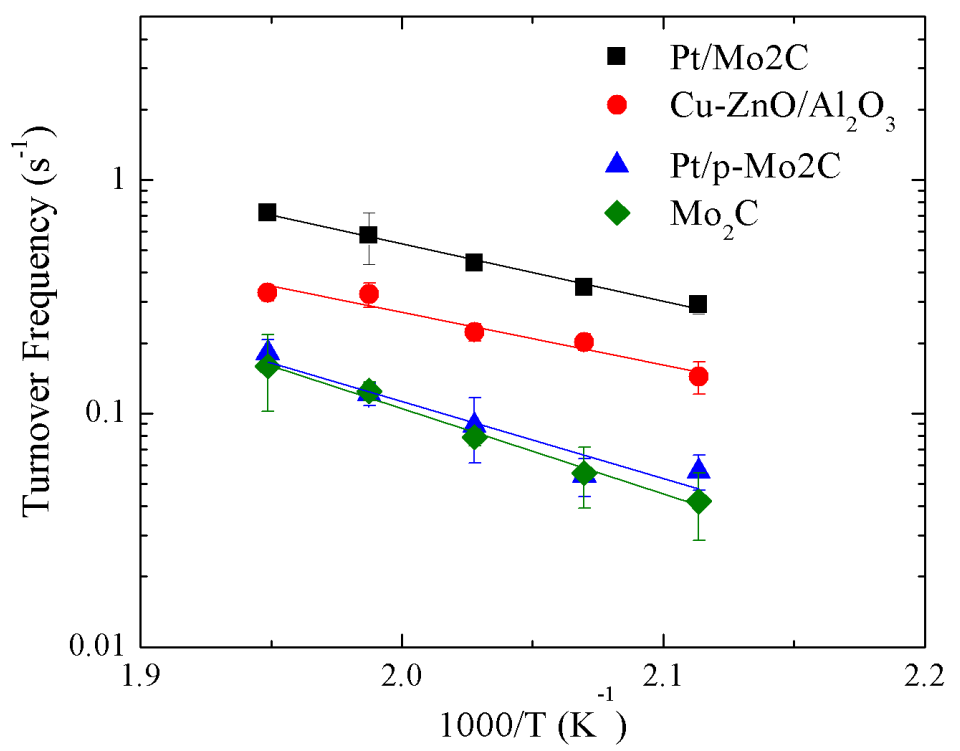

Figure 9. Arrhenius plot illustrating turnover frequencies (normalized by $\mathrm{CO}$ uptake capacity) of the $\mathrm{Mo}_{2} \mathrm{C}$ based catalysts and the commercial $\mathrm{Cu}-\mathrm{ZnO} / \mathrm{Al}_{2} \mathrm{O}_{3}$. 


\section{Discussion}

Results described in this paper revealed significant differences between the synthesis chemistries, structures and compositions of catalysts produced by depositing Pt onto unpassivated and passivated $\mathrm{Mo}_{2} \mathrm{C}$ supports, and are consistent with the proposal by Schaidle et al. [25] that the deposition of $\mathrm{Pt}$ onto $\mathrm{Mo}_{2} \mathrm{C}$ proceeded via electrostatic adsorption of an anionic $\mathrm{Pt}$ species onto the carbide surface, followed by reduction of $\mathrm{Pt}$ in that species. Shelimov et al. reported that $\left[\mathrm{PtCl}_{6}\right]^{2-}$ and [ $\left.\mathrm{PtCl}_{5}\left(\mathrm{H}_{2} \mathrm{O}\right)\right]^{-}$are the dominant species in aqueous solutions of $\mathrm{H}_{2} \mathrm{PtCl}_{6}$ [33]. The $\mathrm{pH}$ of $\mathrm{H}_{2} \mathrm{PtCl}_{6}$ solutions used in our research was consistently $\sim 2.2$. Given this and literature regarding metal adsorption through electrostatic interactions $[28,29,34,35],\left[\mathrm{PtCl}_{6}\right]^{2-}$ and $\left[\mathrm{PtCl}_{5}\left(\mathrm{H}_{2} \mathrm{O}\right)\right]^{-}$should be attracted to and deposited onto the $\mathrm{Mo}_{2} \mathrm{C}$ surface $\left(\mathrm{PZC} \sim 5\right.$ ). With a PZC of 3, the electrostatic adsorption of $\left[\mathrm{PtCl}_{6}\right]^{2-}$ and $\left[\mathrm{PtCl}_{5}\left(\mathrm{H}_{2} \mathrm{O}\right)\right]^{-}$would be less favorable for $\mathrm{p}-\mathrm{Mo}_{2} \mathrm{C}$, nevertheless, some degree of adsorption should occur. For the $\mathrm{Mo}_{2} \mathrm{C}$ material, the XAS results indicated that $\mathrm{Pt}^{4+}$ in $\left[\mathrm{PtCl}_{6}\right]^{2-}$ was reduced to $\sim \mathrm{Pt}^{0}$ with concomitant oxidation of Mo, perhaps according to the reaction in Equation 1. This redox interaction likely facilitated the formation of highly dispersed $\mathrm{Pt}$ domains on the $\mathrm{Mo}_{2} \mathrm{C}$ surface.

$$
\mathrm{Mo}_{2}^{x} \mathrm{C}+\delta\left[\mathrm{PtCl}_{6}\right]^{2-} \rightarrow \mathrm{Mo}_{2}^{x+4 \delta} \mathrm{C}+\mathrm{Pt}^{0}+6 \mathrm{Cl}_{(a d s)}^{-}
$$

Schaidle et al. observed chlorine on the surfaces of the materials following the deposition of Pt from $\mathrm{H}_{2} \mathrm{PtCl}_{6}$ solutions [25]. It is likely that chloride anions complex with the surface following Pt reduction in order to balance the surface charge. Passivation, an oxidation of the $\mathrm{Mo}_{2} \mathrm{C}$ surface from $\mathrm{Mo}^{-2+}$ to $\mathrm{Mo}^{4+} / \mathrm{Mo}^{6+}$, would be expected to inhibit redox chemistry with the Pt salts resulting in very different structural and compositional properties when compared to materials produced using the unpassivated materials. By oxidizing the $\mathrm{Mo}_{2} \mathrm{C}$ surface (which serves as the reducing agent for $\mathrm{Pt}$ ) prior to interaction with $\mathrm{H}_{2} \mathrm{PtCl}_{6}$, the driving force for redox chemistry is reduced or removed as, in a oxidized state, Mo is less willing to donate electrons to Pt. Regarding differences in catalyst compositions, we believe that the lower loading for the passivated $\mathrm{Mo}_{2} \mathrm{C}$ was due to either removal of some of the deposited $\mathrm{Pt}$ 
during the dissolution of the passivation layer or complexation between the dissolved oxycarbide and the Pt metal salt. These possibilities are being investigated.

The WGS rates and TOFs for the Pt/Mo $2 \mathrm{C}$ catalyst were higher to those for the $\mathrm{Pt} / \mathrm{p}-\mathrm{Mo}_{2} \mathrm{C}$ catalyst despite being recarburized prior to the rate measurements. One might expect that recarburization of these materials would yield catalysts with similar performance characteristics including activation energies, however, this was not the case. This observation as well as details regarding synthesis of the materials illustrates the consequence of passivation prior to deposition of the Pt particles. Given the higher activities, depositing Pt directly onto the carbide surface is preferred.

Differences between TOFs and activation energies for the $\mathrm{Pt} / \mathrm{Mo}_{2} \mathrm{C}$ and $\mathrm{Pt} / \mathrm{p}-\mathrm{Mo}_{2} \mathrm{C}$ catalysts suggest that active sites for these catalysts were different. Schweitzer et al. [11] proposed that the most active sites for WGS on the $\mathrm{Pt} / \mathrm{Mo}_{2} \mathrm{C}$ catalysts were at the interface between the Pt particle and $\mathrm{Mo}_{2} \mathrm{C}$ surface. The results were consistent with $\mathrm{H}_{2} \mathrm{O}$ activation on $\mathrm{Mo}_{2} \mathrm{C}$, producing oxygen for subsequent reaction with $\mathrm{CO}$ at the interface; the adsorption of $\mathrm{CO}$ was facilitated by the Pt. Given that rates, TOFs and activation energies for the $\mathrm{Pt} / \mathrm{p}-\mathrm{Mo}_{2} \mathrm{C}$ and $\mathrm{p}-\mathrm{Mo}_{2} \mathrm{C}$ catalysts were nearly identical we believe that most of the activity was derived from the $\mathrm{p}-\mathrm{Mo}_{2} \mathrm{C}$ and that the $\mathrm{Pt}$ was relatively inactive. This is not inconsistent with the very large sizes for $\mathrm{Pt}$ particles on the $\mathrm{Pt} / \mathrm{p}-\mathrm{Mo}_{2} \mathrm{C}$ catalyst, in particular when compared to those on the $\mathrm{Pt} / \mathrm{Mo}_{2} \mathrm{C}$ catalysts. Assuming $19 \mu \mathrm{m}$ spherical particles, the $\mathrm{Pt}$ would account for $1.6 \times 10^{-4} \mathrm{~m}^{2}$ or less than $0.001 \%$ of the surface area of the $1.1 \% \mathrm{Pt} / \mathrm{p}-\mathrm{Mo}_{2} \mathrm{C}$ catalyst. Finally we offer a comment about similarities between rates for the $\mathrm{Pt} / \mathrm{Mo}_{2} \mathrm{C}$ and $\mathrm{Pt} / \mathrm{p}-\mathrm{Mo}_{2} \mathrm{C}$ catalysts when normalized by the Pt content. This similarity may have been a coincidence. For catalysts where the activity is dominated by the $\mathrm{p}-\mathrm{Mo}_{2} \mathrm{C}$, mathematically, there will be one loading where the Pt normalized rates for the $\mathrm{Pt} / \mathrm{Mo}_{2} \mathrm{C}$ and $\mathrm{Pt} / \mathrm{p}-\mathrm{Mo}_{2} \mathrm{C}$ catalysts should be identical. This possibility is being investigated.

\section{Conclusions}


Research described in this paper focused on determining the similarities and differences between structural, compositional and catalytic properties of materials produced by depositing $\mathrm{Pt}$ onto unpassivated and passivated $\mathrm{Mo}_{2} \mathrm{C}$. The results indicate that the catalytic and structural properties of the $\mathrm{Pt} / \mathrm{Mo}_{2} \mathrm{C}$ and $\mathrm{Pt} / \mathrm{p}-\mathrm{Mo}_{2} \mathrm{C}$ catalysts were very different. Platinum deposition for the $\mathrm{Pt} / \mathrm{Mo}_{2} \mathrm{C}$ catalyst was governed primarily by redox reactions between the Pt precursor and $\mathrm{Mo}$ in $\mathrm{Mo}_{2} \mathrm{C}$ with the $\mathrm{Pt}$ being reduced and the Mo being oxidized. This type of interaction was inhibited for the $\mathrm{p}-\mathrm{Mo}_{2} \mathrm{C}$ supported material due to the presence of the passivation layer. As a consequence, the Pt structures and catalyst compositions were impacted and the intrinsic water-gas shift activities of the $\mathrm{Pt} / \mathrm{Mo}_{2} \mathrm{C}$ and $\mathrm{Pt} / \mathrm{p}-\mathrm{Mo}_{2} \mathrm{C}$ catalysts were very different. The $\mathrm{Pt} / \mathrm{Mo}_{2} \mathrm{C}$ catalyst was much more active than the $\mathrm{Pt} / \mathrm{p}-\mathrm{Mo}_{2} \mathrm{C}$ catalyst. In conclusion, the results indicate that the passivation layer can have a larger impact on metal-support interactions than has been previously discussed and this should be considered during the synthesis of carbide- and nitride-supported metal catalysts.

\section{ASSOCIATED CONTENT}

Please see supporting information for additional content.

\section{AUTHOR INFORMATION}

\section{Corresponding Author}

Levi T. Thompson - ltt@umich.edu

\section{ACKNOWLEDGMENT}

The authors would like to acknowledge partial financial support from the NSF under the CCI Center for Enabling New Technologies through Catalysis (CENTC) Phase II Renewal, CHE-1205189. In addition assistance and support from Gaowei Wang, Anisha Rehlan, Siu On Tung, Dr. Tanya Breault, and Yuan Chen is acknowledged. Use of the Advanced Photon Source at Argonne National Laboratory was supported by the U. S. Department of Energy, Office of Science, Office of Basic Energy Sciences, under 
Contract No. DE-AC02-06CH11357. MRCAT operations are supported by the Department of Energy

and the MRCAT member institutions. Scanning electron microscopy was performed in the Electron

Microbeam Analysis Laboratory at the University of Michigan (NSF DMR-0420785).

\section{REFERENCES}

[1] M. Delgado, C.C. Santini, F. Delbecq, R. Wischert, B. Le Guennic, G. Tosin, R. Spitz, J.-M. Basset, P. Sautet, J. Phys. Chem. C, 114 (2010) 18516-18528.

[2] X. Wang, J.A. Rodriguez, J.C. Hanson, D. Gamarra, A. Martínez-Arias, M. Fernández-García. J. Phys. Chem. B, 110 (2006) 428-434.

[3] S.J. Tauster, Acc. Chem. Res., 20 (1987) 389-394.

[4] B.L. Mojet, M.J. Kapper, J.T. Miller, D.C. Koningsberger, Studies in Surf. Sci. and Cat., 101 (1996) 1165-1174.

[5] K. Keyvanloo, H.C. Hecker, B.F. Woodfield, C.H. Bartholomew, J. Catalysis., 319 (2014) $220-231$.

[6] K. Cheng, V.V. Ordomsky, M. Virginie, B. Legras, P.A. Chernavskii, V.O. Kazak, C. Cordier, S. Paul, Y. Wang, A.Y. Khodakov, Appl. Cat. A: General, 488 (2014) 66-77.

[7] K.G. Azzam, I.V. Babich, K. Seshan, L. Lefferts, J. Catalysis, 251 (2007) 153-162.

[8] A. Centeno, E. Laurent, B. Delmon, J. Catalysis, 154 (1995) 288-298.

[9] D.V. Esposito, S.T. Hunt, Y.C. Kimmel, J.G. Chen, J. Am. Chem. Soc., 134 (2012) 3025-3033.

[10] J.A. Rodriguez, P. Liu, Y. Takahashi, K. Nakamura, F. Viñes, F. Illas, J. Am. Chem. Soc., 131 (2009) 8595-8602.

[11] N.M. Schweitzer, J.A. Schaidle, O.K. Ezekoye, X. Pan, S. Linic, L.T. Thompson, J. Am. Chem. Soc., 133 (2011) 2378-2381.

[12] N. Perret, X. Wang, L. Delannoy, C. Potvin, C. Louis, M.A. Keane, J. Catalysis., 286 (2012) 172183.

[13] S.T. Oyama, Catal. Today. 15 (1992) 179-200.

[14] R.J. Colton, J.J. Huang, R.W. Rabalais, Chem. Phys. Letters., 34 (1975) 337-339.

[15] M. Lewandowski, A. Szymańska-Kolasa, P. Da Costa, C. Sayag, Catal. Today, 119 (2007) 31-34.

[16] M. Xiang, D. Li, H. Xiao, J. Zhang, W. Li, B. Zhong, Y. Sun, Catal. Today, 131 (2008) 489-495.

[17] H. Shou, R.J. Davis, J. Catalysis, 282 (2011) 83-93.

[18] A, Griboval-Constant, J. Giraudon, G. Leclercq, L. Leclercq, Appl. Cat. A: General, 260, (2004)3545.

[19] A. Griboval-Constant, J. Giraudon, I. Twagishema, G. Leclercq, M.E. Rivas, J. Alvarez, M.J. Pérez-Zurita, M.R. Goldwasser, J. Molec. Cat. A: Chemical, 259 (2006) 187-196.

[20] W. Setthapun, S.K. Bej, L.T. Thompson, Top. Catal., 49 (2008) 73-80.

[21] A.C. Lausche, J.A. Schaidle, L.T. Thompson, Appl. Cat. A: General, 401 (2011) 29-36.

[22] J.A. Schaidle, A.C. Lausche, L.T. Thompson, J. Catalysis., 272 (2010) 235-245.

[23] I.J. Hsu, Y.C. Kimmel, X. Jiang, B.G. Willis, J.G. Chen, Chem. Commun., 48 (2012) 1063-1065.

[24] R. Venkataraman, H.R. Kunz, J.M. Fenton, J. Electrochem. Soc., 150 (2003) A278-A284. 
[25] J.A. Schaidle, N.M. Schweitzer, O.T. Ajenifujah, L.T. Thompson, J. Catalysis, 289 (2012) 210217.

[26]H. Shou, D. Ferrari, D.G. Barton, C.W. Jones, R.J. Davis, ACS Catal., 2 (2012) 1408-1416.

[27] D.D. Wagman, W.H. Evans, V.B. Parker, I. Halow, S.M. Baily, R.H. Schumm. Selected Values of Chemical Thermodynamic Properties, Institute for Basic Standards, National Bureau of Standards, Washington D.C., 1965.

[28] L. Jiao, J.R. Regalbuto, J. Catalysis, 260 (2008) 329-341.

[29] T.E. Feltes, L. Espinsoa-Alonso, E. de Smit, L. D’Souza, R.J. Meyer, B.M. Weckhuysen, J.R. Regalbuto, J.R. J. Catalysis, 270 (2010) 95-102.

[30] B. Ravel, M. Newville, Journal of Synchrotron Radiation, 12 (2005) 537-541.

[31] G. Wang, J.A. Schaidle, M.B. Katz, Y. Li, X. Pan, L.T. Thompson, J. Catalysis, 304 (2013) 92-99. [32] J. Patt. PhD. Thesis. University of Michigan, 2003.

[33] B. Shelimov, J.-F. Lambert, M. Che, B.J. Didillon, Am. Chem. Soc., 121 (1999) 545-556.

[34] J.-F. Lambert, M. Che, J. Mol. Catal. A: Chem. 162 (2000) 5-18.

[35] J.P. Brunelle, Pure Appl. Chem. 50 (1978) 1211-1229. 
Graphical Abstract for "Effects of Passivation on Synthesis, Structure and Composition of Molybdenum Carbide Supported Platinum Water-Gas Shift Catalysts"

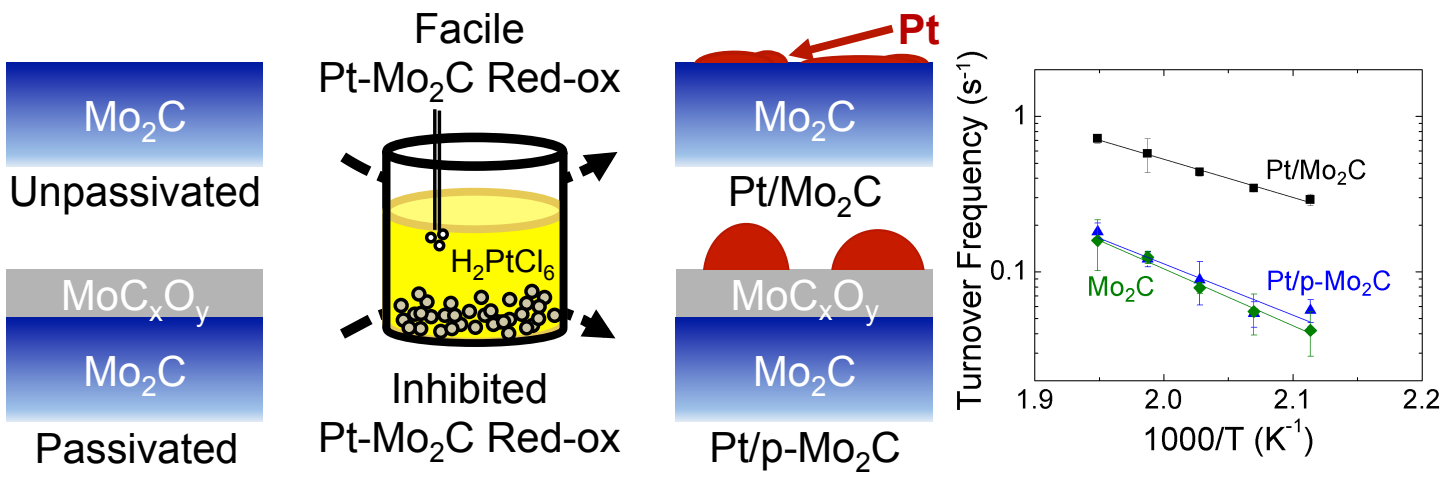

